\title{
Against the Grain
}

Volume 24 | Issue 1

Article 6

February 2012

\section{Claflin University Implements Successful Information Literacy Program}

Shanesha R. F. Brooks-Tatum

HBCU Library Alliance, sbrooks-tatum@hbculibraries.org

Follow this and additional works at: https://docs.lib.purdue.edu/atg

Part of the Library and Information Science Commons

\section{Recommended Citation}

Brooks-Tatum, Shanesha R. F. (2012) "Claflin University Implements Successful Information Literacy Program," Against the Grain: Vol. 24: Iss. 1, Article 6.

DOI: https://doi.org/10.7771/2380-176X.6076

This document has been made available through Purdue e-Pubs, a service of the Purdue University Libraries. Please contact epubs@purdue.edu for additional information. 


\section{Claflin University Implements Successfull Information}

Liiteracy Program

by Shanesha R. F. Brooks-Tatum (Project Coordinator/Writer, HBCU Library Alliance) <sbrooks-tatum@hbculibraries.org>

$\mathrm{C}$

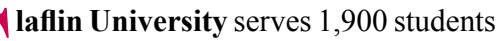
in Orangeburg, South Carolina. Founded in 1869 , the University is affiliated with the United Methodist Church and is the oldest Historically Black College or University in South Carolina. Named after the university's sixth president, the H.V. Manning Library officially opened on December 3, 1967, and it was fully renovated in 2001-2002. It attends to the educational, occupational, and research needs of a small but diverse student and faculty population. The Library's mission is to support and supplement teaching and learning throughout the University.

Claflin University's archives have doubled in size since it opened, and the Library now houses smart technology, including an interactive projection display with a white board, podium, and wireless technology. In 2010, through the HBCU Library Alliance/ASERL Librarian Exchange Program, the Library implemented an information literacy program. As an exchange librarian at East Carolina University in Greenville, North Carolina, Claflin University Librarian Morgan Montgomery gained the skills and knowledge to design the Library's Information Literary Program, a series of standard informa-

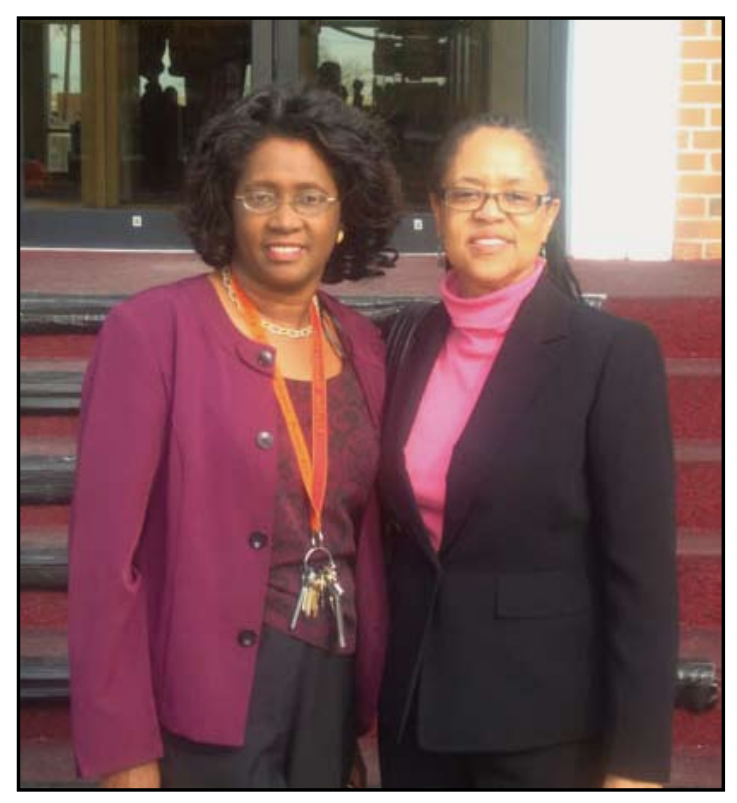

Ms. Marilyn Y. Gibbs, Library Director, Claflin University, and Ms. Sandra Phoenix, Executive Director, HBCU Library Alliance, on the steps of the Claflin University's H.V. Manning Library from the December 2009 site visit. Photo (C) The HBCU Library Alliance.

tion literacy classes for freshman, upper-level, and thesis-level research. Montgomery learned lesson planning, assessment, effective presentation skills, and teaching methodologies that address various learning styles. She learned how to create subject guides using LibGuides and how to use Skype when delivering virtual reference services.

According to Montgomery, it was imperative that she take a multifaceted approach and be informed about various teaching methodologies because students learn in different ways. She recommends conducting a literature review to find out what components of information literacy to teach and how to construct proper student learning outcomes when designing an information literacy lesson plan.

Outreach has been the key to the successful implementation of the H.V. Manning Library information literacy program. A handout and information sessions at faculty meetings highlight the resources available in the H.V. Manning Library. Faculty members collaborate with the Library and create subject-specific assignments for students to better utilize the Library's resources. For example, Montgomery was a guest lecturer on the issue of "Banned Books and Freedom of Speech" for an Introduction to Mass Communications class.

"Teamwork is the key to ensuring the H.V. Manning Library's continued success in working with students, staff, and faculty," Montgomery explained. "The Library staff is what makes our library a success. The cross-training project that the staff participated in through the HBCU Library Alliance has ensured that staff members are prepared to respond to the needs of our patrons," added Marilyn Y. Gibbs, Library Director.

Because of the successful implementation of this information literacy program, a campus plan was approved and implemented in 2010, which aims to improve information literacy and increase knowledge of research methods. The campus plan, titled "Enhancing Quality Reference, Research and Services: The Evolution of the Reference and Research Center of Excellence in the H.V. Manning Library," will create a new information literacy librarian position and research, resources, and services to maintain and enhance the reference department.
University president, Dr. Henry N. Tisdale and Interim Vice President for Academic Affairs, Dr. Vermelle Johnson have been supportive of library innovation and programming. The success of this project is reflected not only by the University's willingness to provide additional personnel and resources, but also by the increased number of information literacy

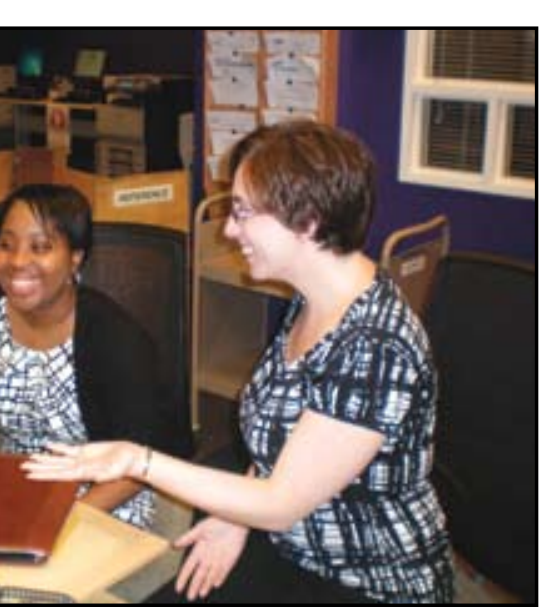
Montgomery, Reference Librarian, Claflin University, and Mrs. Amy Gustavson, Instructional Services Coordinator, Joyner Library East Carolina University, discussing information literacy issues. Photo (C) Ms. Morgan Montgomery.

classes that were scheduled this academic year as compared to previous years.

The campus plan has been in effect only a year, but the results to date are positive and promising. Information literacy sessions have increased from 21 sessions serving 300 students and faculty in 2009 to 66 sessions serving 1,605 participants from January 2010 to August 2011. Feedback from students has been positive. In anonymous surveys, students reported that they felt comfortable navigating the databases. One participant stated, "I have taken this 'research presentation' before, but I still learned something new today." Another stated, "Learning how to use the Library's Website to look up information about my essay was most useful." Several faculty members have written letters thanking the H.V. Manning Library for providing this service.

Montgomery suggests the following methods for library improvements:

1. Reach out. Contact local HBCUs, colleges, or universities in your area to gain insight on how they made their programs work.

2. Write the vision. Create a vision statement to summarize the aim of your information literacy program.

continued on page 16 
3. Define your student learning outcomes. What is the focus of your lesson? What key points do you want your students to take away? Incorporate an activity that summarizes what you have taught.

4. Network. Partner with faculty and staff members on your campus. Having people onboard makes it easier to get the message out. This semester faculty members specifically asked their students to stop by the library if they have questions. This has helped students become more comfortable asking for help.

Montgomery shared that she has been affected by the information literacy program personally and professionally: "My definition of information literacy has been enhanced," she reflects. "I believe, aside from teaching students how to locate, evaluate, and utilize information, you must make the entire process relevant. By engaging students in discussions, various instruction methods, utilizing assessment tools, and connecting the process to real life experiences, the students will be able to see the big picture."

For more information about the H.V. Manning Library, visit $h t t p: / / w w w$. claflin.edu/library/index.asp.

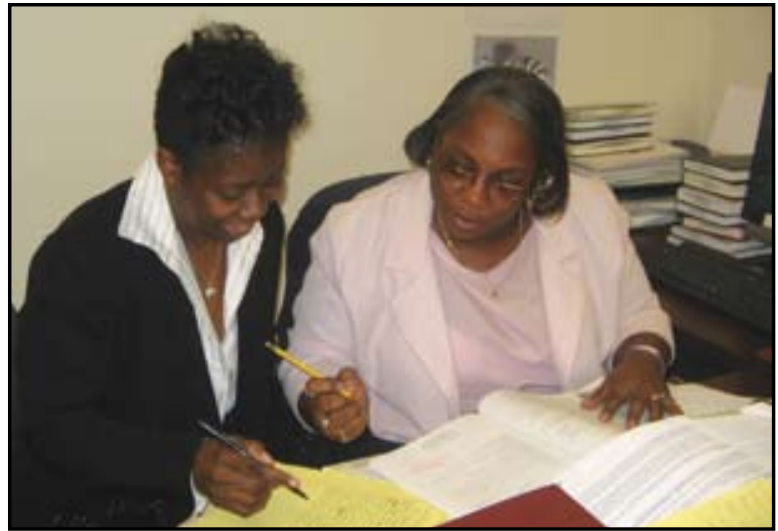

Mrs. Bernestine Haynes, Library Assistant (Serials Department), and Mrs. Mamie Huggins, Library Assistant (Technical Services), engaging in cross-training. Photo (C) Ms. Marilyn Y. Gibbs.

\section{Delaware State University Gruides Patrons into More Effective Research with Standardized Lib Gruides}

\section{by Shanesha R. F. Brooks-Tatum (Project Coordinator/Writer, HBCU Library Alliance) <sbrooks-tatum@hbculibraries.org>}

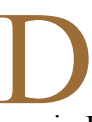
elaware State University serves nearly 4,000 students on its 400 -acre campus. The oldest building on campus is Loockerman Hall, a restored national historic landmark from the 1700 s that once served as the center of campus. In 1971, the building was placed on the National Register of Historic Places by the National Park Service. Loockerman Hall functioned as the center of resources for the then "Delaware College for Colored Students" and as a guide and a haven to slaves traveling the Underground Railroad. Today at Delaware State University's William C. Jason Library, innovative LibGuides, or library guides, are the central resources for student and faculty research.

LibGuides are electronic guides for subjectspecific resources. Mr. Jéan M. Charlot, Systems/Library Technology Officer, explained that prior to developing LibGuides, the library used subject guides, which were separate Web pages linked to the library's Website. The subject guides provided limited information and

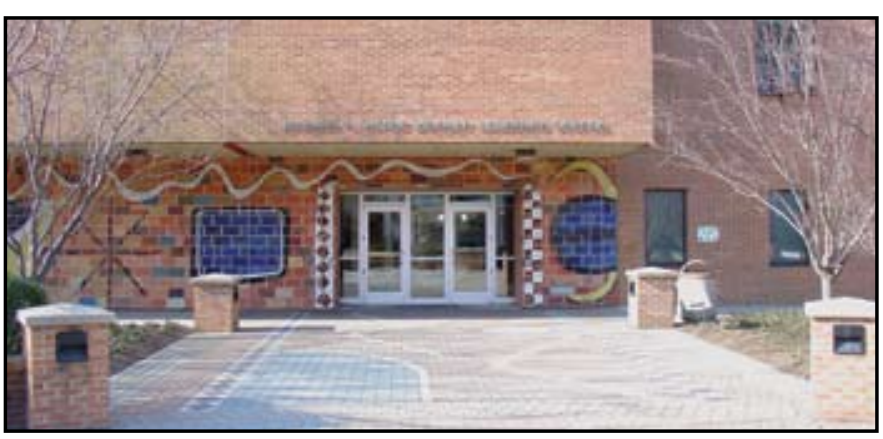

The front entrance to the William C. Jason Library. All photos included with this article are courtesy of Delaware State University. to create LibGuides. available. were not easy to update and expand, since not all librarians had access to the Web design software. Librarians at the reference desk were inundated with questions and inquiries from students and faculty. "Since we have a small staff, it was challenging for us to quickly and effectively address all of the questions that we were getting," Charlot reflected. The library staff set about securing Title III funding

Beverly Charlot, Coordinator of Technical Services, created a "onestop-shop" LibGuide for students to use. With very specific subject headings, searchable eBooks, and a new database tab, students who do not have specific questions or who are trying to figure out the direction of their research projects can browse and get a sense of what is

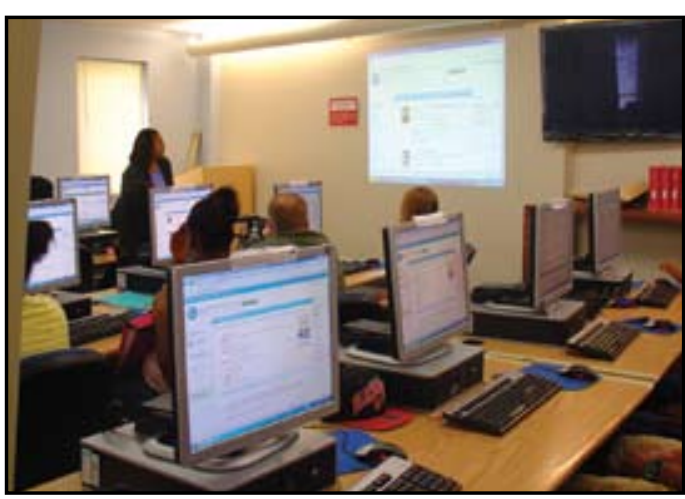

Shown above: Librarian Beverly Charlot leads an instruction session. Below: Students use computers at terminal near the library front entrance.

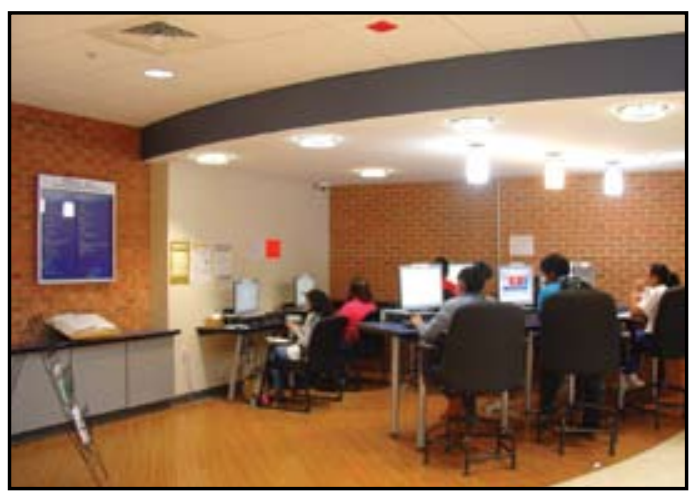
that students have even more immediate access to librarians and the ability to quickly request items not offered by Delaware State. The library's interlibrary loan statistics show that in 2010, there were 759 requests. As of October 2011 , there have been 870 requests, a nearly 15 percent increase, not including the remainder of the year.

continued on page 18 